\author{
HANNA GODLEWSKA-MAJKOWSKA \\ Szkoła Główna Handlowa, Warszawa, Polska \\ Warsaw School of Economics, Poland \\ JACEK LIPIEC \\ Szkoła Główna Handlowa, Warszawa, Polska \\ Warsaw School of Economics, Poland
}

\title{
Zarządzanie różnorodnością pokoleniową zasobów pracy w przestrzeni regionalnej Polski
}

\section{Managing Generational Diversity of Human Resources in the Polish Regional Spatial Context}

\begin{abstract}
Streszczenie: Współczesne warunki życia spowodowały wydłużenie trwania życia i koegzystencję wielu pokoleń. Na rynku pracy mogą obecnie funkcjonować równocześnie tradycjonaliści oraz pokolenie Z, co stanowi wyzwanie dla zarządzających firmą oraz włodarzy jednostek samorządu terytorialnego. Dla regionu istotne jest zarówno pokolenie najmłodsze, które jest biegłe w korzystaniu z narzędzi informatycznych (gospodarka cyfrowa), jak i starsze pokolenie, które jest nośnikiem wiedzy. Wobec powyższego autorzy określili cel niniejszego artykułu jako identyfikację źródeł różnorodności pokoleniowej zasobów pracy i jej zróżnicowania przestrzennego w Polsce, a także wskazanie tendencji przestrzennych w rozwoju różnorodności pokoleniowej w latach 2003-2016 w skali powiatów. Ponadto artykuł wskazuje kluczowe obszary zarządzania generacjami w różnych skalach (od mikroekonomicznej przez mezoekonomiczną do krajowej), pozwalającego na uzyskanie wzmocnionego efektu synergicznego w zespołach międzypokoleniowych oraz niwelującego negatywne skutki różnorodności pokoleniowej. Z analizy trendów przestrzennych w kształtowaniu się demograficznej wymienialności pokoleń wynika, że milenialsi stanowią w skali kraju pokolenie o zmniejszającym się udziale w zaludnieniu w latach 2003-2016, ale to właśnie oni, wraz z nadchodzącym pokoleniem Z, będą kształtować w najbliższych latach rynek pracy, zwłaszcza w Wielkopolsce, na Pomorzu i Warmii oraz Mazurach. Jednak srebrną gospodarkę należy postrzegać jako szansę do wykorzystania przez regiony, np. poprzez rozwój opieki senioralnej. W kontekście rynku pracy kluczowe jest zrozumienie tego zagadnienia oraz stworzenie odpowiedniej komunikacji międzypokoleniowej w miejscu pracy.
\end{abstract}

\begin{abstract}
Current living conditions have contributed to the longer life expectancy and the co-existence of multiple generations. Today, the silent generation and generation $\mathrm{Z}$ can exists simultaneously on the labour market that is challenging both for managers and local governors. Both the youngest generation, who are eloquent in using IT (digital economy), and older generation, who are the knowledge transmitter, are important for regions. According to these assumptions, the authors have defined the goal of this article as the identification of sources of generational diversity in the context of the labour demands and its spatial diversity in Poland. In addition, spatial tendencies in the development of generational diversity of local counties between 2003 and 2016 was provided. The article indicates the key areas of managing diversity across different scales (microeconomic, mezzo-economic and country) that allow obtaining the synergy of intergenerational teams and diminishing negative effects of generational diversity. The spatial trends analysis in the context of re-
\end{abstract}


placement of generations proves that the quota of millennials in Poland diminished between 2003 and 2016. This generation with the forthcoming generation $\mathrm{Z}$ will shape the labour market in years to come, in particular in Greater Poland, Pomerania, and Warmia and Masuria. However the silver economy has to be perceived as the opportunity to capture by regions, e.g. by delivering senior healthcare. The adequate communication channels for different generations have to be understood and offered in the labour market.

Słowa kluczowe: gospodarka srebrna; pokolenie; polityka regionalna; różnorodność międzypokoleniowa; współczynnik obciążenia demograficznego

Keywords: age dependency ratio; generation; generational diversity; regional policy; silver economy

Otrzymano: 22 grudnia 2017

Received: 22 December 2017

Zaakceptowano: 13 lipca 2018

Accepted: 13 July 2018

Sugerowana cytacja / Suggested citation:

Godlewska-Majkowska, H., Lipiec, J. (2018). Zarządzanie różnorodnością pokoleniową zasobów pracy w przestrzeni regionalnej Polski. Prace Komisji Geografii Przemysłu Polskiego Towarzystwa Geograficznego, 32(3), 9-25. https://doi.org/10.24917/20801653.323.1

\section{WSTĘP}

Socjologowie od dawna zauważyli różnice pokoleniowe i potrzebę badania pokoleniowej odmienności (Eisenstadt, 1956; Eyerman, Turner, 1998). Współczesny postęp technologiczny wpłynął na wzrost długości przeciętnego życia i spowodował, że na rynku pracy zaczęły funkcjonować nawet cztery pokolenia (Shaw, 2013), spośród których najmłodsze to tzw. pokolenie Z (Stillman, D., Stillman, J., 2017). Tak radykalna zmiana demograficzna, kształtująca relacje na współczesnym rynku pracy, powoduje również transformację wielu aspektów współczesnego życia, od rewizji stosunków pracy w skali mikroekonomicznej po zmianę polityki regionalnej. W konsekwencji tych przeobrażeń wyzwaniem staje się umiejętne prowadzenie komunikacji międzygeneracyjnej, motywowanie do pracy czy też uwzględnianie odmiennych systemów wartości związanych z różnymi grupami społecznymi w wielu aspektach życia (Martin, Tulgan, 2002; Parry, Urwin, 2011). Zarówno na szczeblu krajowym, jak i regionalnym, problem różnorodności pokoleniowej dotyczy szczególnie tych regionów, w których doszło do deformacji struktur demograficznych w wyniku selektywności migracji oraz długotrwałych tendencji starzenia się ludności.

Celem niniejszego artykułu jest identyfikacja źródeł różnorodności pokoleniowej zasobów pracy i jej zróżnicowania przestrzennego w Polsce, a także wskazanie tendencji przestrzennych w rozwoju różnorodności pokoleniowej w latach 2003-2016 w skali powiatów. Dodatkowo artykuł ma na celu wskazać kluczowe obszary zarządzania zasobami pracy w różnych skalach, od mikroekonomicznej przez mezoekonomiczną do krajowej, by nie tylko zmniejszać negatywne skutki różnorodności pokoleniowej, ale też wzmacniać efekt synergiczny, wynikający z tworzenia zespołów międzypokoleniowych.

Zasoby pracy są traktowane w sposób szerszy niż odniesienie do ludności w wieku produkcyjnym. W analizach uwzględniamy zarówno pokolenia osób starszych, reprezentujących grupę zwykle uważaną za poprodukcyjną, jak i pokolenie urodzone po 2000 roku. Wychodzimy bowiem z założenia, że wśród osób, które ukończyły 65 lat, mogą być osoby nadal czynne zawodowo, zwłaszcza reprezentujące przedsiębiorczość rodzinną. Podobnie najstarsze osoby z pokolenia Z mogą już wspierać firmy swoich 
krewnych, czy wręcz zakładać swoje pierwsze start-upy. Szczególnie w firmach rodzinnych mogą zatem tworzyć się zespoły wielopokoleniowe, wymagające identyfikacji wyzwań związanych z ich strukturą demograficzną.

\section{DLACZEGO RÓŻNORODNOŚĆ POKOLENIOWA STAJE SIĘ WAŻNYM ELEMENTEM W ZARZĄDZANIU ZASOBAMI PRACY}

Współczesne globalne zmiany generacyjne kształtujące różne aspekty życia społeczno-gospodarczego wymagają pogłębionych analiz (Edmunds, Turner, 2005). I.C. Woodward, P. Vongswasdi i E.A. More (2015) twierdzą, że współczesne badania nad generacjami są ograniczone i nie prowadzą do jednoznacznych wniosków, czyli część z nich potwierdza wpływ różnorodności pokoleniowej na życie społeczno-gospodarcze, zaś pozostałe - że taka korelacja nie występuje. O ile różnorodność w ujęciu płci bądź rasowym jest stosunkowo dobrze rozpoznana, o tyle badania w tym zakresie nie mogą być rozstrzygające, gdyż znajdują się we wczesnym stadium badawczym (Shore i in., 2009). Należy również zauważyć, że badanie różnorodności pokoleniowej - w odróżnieniu od innego rodzaju różnorodności - jest bardzo istotne, gdyż człowiek w trakcie swojego życia przechodzi przez cykle pokoleniowe, co wywołuje zmiany w sposobie jego funkcjonowania (Erikson, 2012).

Współcześnie zachodzące zmiany demograficzne można wytłumaczyć, odwołując się do prac amerykańskiej antropolog M. Mead. Według niej znajdujemy się obecnie w modelu prefiguratywnym zmian społeczno-kulturowych, zgodnie z którym młodzi wykorzystują nowe technologie, zmieniając świat, zaś ich rodzicie próbują za nimi nadążać, często się od nich ucząc (Mead, 1978: 25). Młodzi (głównie pokolenie Z) tworzą już nową kulturę opartą na nowych technologiach, przyczyniając się do coraz większego rozdźwięku pomiędzy nimi a rodzicami, który jeszcze bardziej się uwydatnia w stosunku do dziadków (Loges, Jung, 2001; Shelley, Thrane, Shulman, 2006; Elmore, 2010; Oh, Reeves, 2014). Nowe technologie powodują, że tradycja, wartości oraz więzi międzypokoleniowe ulegają radykalnemu przeobrażeniu. Ponadto wpływają one na pogłębianie się różnic między pokoleniami i często prowadzą do przepaści między tymi, którzy są biegli w nowych technologiach, a tymi, którzy za nimi nie nadążają. Takie tendencje są zgodne $\mathrm{z}$ determinizmem technologicznym, według którego nowe technologie stają się autonomiczne (Winner, 1977), znacząco determinując ogólny postęp ludzkości (Segal, 1985). Zatem ważnym zadaniem wydaje się być wnikliwe obserwowanie zmian technologicznych, które w efekcie prowadzą do przekształcania stosunków społecznych. Transformację współczesnych stosunków społecznych potęgują również inne czynniki. G. Mendel zauważył, że następuje kryzys autorytetu społeczeństwa, w tym rodziny, który pojawił się w wyniku procesu globalizacji (Mendel, 2006). Według niego tak radykalne zmiany utrudniają łagodzenie lęków atawistycznych.

Omawiając zarządzanie różnorodnością pokoleniową, należy przytoczyć jeszcze jeden istotny czynnik przekładający się na dobrobyt gospodarczy, a mianowicie mobilność. W szczególności mobilność osób w wieku produkcyjnym jest kluczowa dla transferu wiedzy oraz innowacyjności przekładającej się na wzrost bądź spadek liczby patentów (Mansfield, 1985; Rogers, 1995; Almeida, Kogut, 1999). W wielu badaniach naukowych zwraca się uwagę na rolę, jaką w podnoszeniu innowacyjności regionu odgrywa regionalna mobilność. Relację taką zaobserwowano już dawno w Dolinie Krzemowej (Saxenian, 
1994), a potwierdziły ją późniejsze badania (Breschi, Lissoni, 2005). Jednak inni badacze zauważają, że mimo istniejących publikacji dokumentujących związek pomiędzy mobilnością osób w wieku produkcyjnym a innowacyjnością, zarówno z perspektywy firmy, jak i regionu, wciąż brakuje badań w tym zakresie (Kaiser, Kongsted, Rønde, 2015). Ponadto twierdzą oni, że z perspektywy teoretycznej nie udowodniono jednoznacznie pozytywnej korelacji pomiędzy większą mobilnością a wyższą innowacyjnością.

Polscy badacze również podejmowali próby analizy i omówienia przestrzennego zróżnicowania przemian demograficznych zachodzących w naszym kraju. S. Kurek (2014) analizował różne zagadnienia demograficzne (m.in. migracje, strukturę wieku ludności itp.), wykorzystując typologię Webba dla powiatów oraz typologię struktury wieku ludności metodą typografów. Wykazał istnienie dużej polaryzacji przestrzennej procesów demograficznych pomiędzy obszarami metropolitalnymi a peryferyjnymi, polegającej na koncentracji ludności w metropoliach, przemieszczaniu się jej do obszarów otaczających miasta oraz wyludnianiu się obszarów peryferyjnych. Z kolei P. Śleszyński (2016), badając uwarunkowania demograficzno-migracyjne, wykazał kształtowanie się hierarchii miast z perspektywy powiązań migracyjnych. Ponadto z jego prognoz wynika, że populacja miast zmniejsza się, zwłaszcza tych średniej wielkości. Badacz twierdzi, że w perspektywie 2050 roku spadek ten wyniesie nawet 40-50\%, co według niego może być częściowo kompensowane imigracją zagraniczną. P. Eberhardt (2014) potwierdza możliwość pozytywnego wpływu imigracji zagranicznej na zahamowanie negatywnych trendów demograficznych. Uważa także, że problematyka depopulacji oraz procesy starzenia się ludności powinny być rozpatrywane w kontekście międzynarodowym -w szczególności unijnym - gdyż granice pomiędzy krajami członkowskimi się zatarły, przyczyniając się do swobodnego przepływu ludności pomiędzy krajami członkowskimi. Jednak polityka migracyjna będzie musiała być korygowana na szczeblu lokalnym, bowiem z jednej strony nastąpi imigracja młodej ludności, wymagająca prowadzenia odpowiedniej polityki prorodzinnej, a z drugiej będzie zwiększał się odsetek ludności starszej, wymagający zmiany polityki socjalnej. Inna badaczka E. Kryńska - omówiła obecne oraz przyszłe zmiany demograficzne zachodzące w Polsce, wskazując ich wpływ na rynek pracy (Kryńska, 2010). Według niej zmiany te wpłyną na zmienność: (1) poziomu oraz rozwoju liczebności zasobów pracy, (2) relacji pomiędzy zbiorowością osób w wieku produkcyjnym, przed- i poprodukcyjnym oraz (3) procesu starzenia się ludności pracującej. Badaczka konkluduje, że zmiany te będą negatywnie oddziaływać na gospodarkę i finanse publiczne kraju.

W związku z powyższym autorzy niniejszej publikacji zakładają kluczową rolę determinizmu technologicznego w kształtowaniu relacji społecznych i podejmują próbę analizy tych zmian w społeczeństwie polskim na poziomie regionalnym. Wnioski z takiej analizy mogłyby posłużyć do kształtowania polityki regionalnej. Zdaniem autorów zarządzający regionami powinni mieć wizję polityki społeczno-gospodarczej uwzględniającej harmonijne funkcjonowanie dwóch i więcej pokoleń, których sposoby zachowania kształtowane są przez determinizm technologiczny. Młodsze pokolenia, które są biegłe w korzystaniu ze współczesnych technologii, powinny być przyciągane do regionów, jako siła napędowa dla lokalnej gospodarki. Jednak starsze pokolenie nie powinno być traktowane jako obciążenie społeczne, ale cenny zasób, którego doświadczenie można i wręcz należy wykorzystać dla regionalnego rozwoju. W przeciwnym razie region może być narażony na ryzyko konfliktów międzypokoleniowych i w konsekwencji 
migracji młodego pokolenia do innych, bardziej otwartych na nową gospodarkę regionów. Ponadto prowadzenie analizy demograficznej w ujęciu współistnienia wielu pokoleń jest istotne dla regionalnego kształtowania rynku pracy, służby zdrowia i innych sfer życia człowieka.

\section{CHARAKTERYSTYKA ORAZ ISTOTA RÓŻNORODNOŚCI POKOLENIOWEJ}

Koncepcję pokolenia można odnaleźć już w starożytności (Joshi, Dencker, Franz, 2011), zaś współcześnie tematykę tę podjął K. Mannheim (1952). Autor ten omawiał pokolenia z perspektywy mechanizmu zmian społecznych. Klasyfikacja, której głównym wyznacznikiem jest przedział wiekowy, wyjaśnia wartości i zachowania jednostek (Lyons, Kuron, 2014). Z tego też względu przyjmuje się współcześnie, że granice określonego pokolenia wyznaczane są poprzez dwa kryteria: przedział wiekowy (age-cohort) oraz wydarzenia o kształcie historyczno-społecznym. Ponadto zauważa się, że pokolenia kształtują tzw. pamięć społeczną poprzez dzielenie wspólnych wartości (Erikson, 2012), zachowań i doświadczeń (Halbwachs, 1950). Wielu badaczy twierdzi, że właśnie te cechy powinny stanowić główny wyróżnik przedziału międzypokoleniowego (Kelan, 2014). Koncepcje ujmowania pokoleń są zatem różne i trudno jest wskazać jednoznacznie kryterium przedziału wiekowego, które klasyfikowałoby osoby urodzone pomiędzy latami granicznymi tego przedziału do określonego pokolenia, gdyż generację może kształtować również perspektywa wydarzeń historycznych (Reither, Hauser, Yang, 2009). Brak jednoznaczności odnośnie do cech kwalifikujących pokolenie (w szczególności innych niż wiek) ogranicza oraz znacząco utrudnia prowadzenie badań z tej tematyki (Giancola, 2006; Dencker, Joshi, Martocchio, 2008).

Pomimo istnienia tych niezgodności klasyfikacyjnych, W. Strauss i N. Howe zaproponowali definicję pokolenia w oparciu o przedział wiekowy, która została powszechnie zaakceptowana przez badaczy. Według nich pokolenie to „grupa-kohorta, której szerokość wyznaczona jest przez rozpiętość fazy życia i której granice wyznacza osobowość" (Strauss, Howe, 1991). Osobowość rozumieją oni jako poczucie przynależności danej jednostki do grupy, będące efektem procesu dojrzewania, przejawiające się podobnym sposobem zachowania i posiadaniem tych samych przekonań oraz spowodowane wystąpieniem podobnych uwarunkowań historycznych.

W. Strauss i N. Howe zaproponowali, aby przedział wiekowy dla pokolenia wynosił 20 lat (1991). To właśnie on oraz wspólne doświadczenia stanowią dzisiaj dominujące kryterium badawcze (Costanza, Badger, Fraser, 2012). Uznaje się, że generacyjny podział społeczeństwa może ułatwiać analizę zachowań konsumenckich (Noble, Haytko, Phillips, 2009), wybory związane z miejscem pracy (Zemke, Raines, Filipczak, 2000), cyfrowe obywatelstwo (Shelley, Thrane, Shulman, Lang, Beisser, Larson, Mutiti, 2004), zaangażowanie i preferencje polityczne (Miller, Shanks, 1996; Wilhelm, 2000; Shelley, Thrane, Shulman, 2015) i kulturowe (Murphy, Gordon, Anderson, 2004) czy praktyki religijne (Maliepaard, Lubbers, Gijsberts, 2010). Powszechne przyjęcie tej definicji oraz propozycji przedziału wiekowego dla generacji spowodowało, że w literaturze zaczęto nadawać specyficzne nazwy dla określonych pokoleń: tradycjonaliści (pokolenie milczące, silent generation, pokolenie dojrzałe, weterani) - urodzeni w latach 1925-1944; baby boomers -1945-1964; pokolenie X (baby bust) - 1965-1979; pokolenie Y (milenialsi, Net Gen, Nexter, Generation Me, Digital Natives) -1980-2000 i pokolenie Z - urodzeni po 2000 roku. 
Tradycjonaliści to pokolenie kształtowane przez wielki kryzys oraz II wojnę światową, stąd najważniejszą dla niego wartością było bezpieczeństwo, zarówno życia zawodowego, jak i życia samego w sobie. Pokolenie to szanuje pracę zawodową oraz przestrzega zasad moralnych. W kontekście technologicznym okres tradycjonalistów naznaczony zostaje przez przekształcenie Computing Tabulating Recording Corporation w International Business Machines Corporation (IBM) w 1924 roku oraz stworzenie pierwszego komputera ENIAC (Electronic Numerical Integrator And Computer - Elektroniczny, Numeryczny Integrator i Komputer) na Uniwersytecie Pensylwanii, który był w stanie rozwiązywać złożone problemy numeryczne.

Z kolei baby boomers to pokolenie powojenne, które wchodziło na polski rynek pracy w gospodarce planowanej centralnie, a następnie musiało skonfrontować się z gospodarką rynkową. Cechuje je zaangażowanie w pracę, którą preferuje wykonywać na zasadzie współpracy, a nie rywalizacji.

Istotną wartość dla tego pokolenia stanowi lojalność. Generacja ta doświadczyła również rewolucji technologicznej. Dla części osób, która była w stanie się dostosować, stworzyła nowe możliwości, zaś pozostałą część wyeliminowała z rynku pracy. Koniec epoki pokolenia baby boomers wyznaczyło wyprodukowanie pierwszego minikomputera z serii PDP przez firmę Digital Equipment Corporation w 1963 roku.

Dla pokolenia X najważniejsza była stabilizacja życia zawodowego oraz rodzinnego. Pokolenie to rozpoczynało pracę zawodową w trudnych czasach transformacji gospodarczej, którą charakteryzowała wysoka stopa inflacji oraz bezrobocia. Z tego też względu jego przedstawiciele cenią stabilizację zawodową, co czyni z nich sumiennych pracowników, wykazujących się wysokim stopniem współpracy, a jednocześnie dbają o rodzinę. Pokolenie X doświadczyło pojawienia się na rynku pierwszych komputerów personalnych powszechnego użytku, czyli ATARI 400 i 600, Sinclair ZX80, Commodore oraz IBM PC.

Pokolenie milenialsów pojawiło się w momencie stworzenia oraz rozwijania internetu przez National Science Foundation. W okresie tym nastąpił również dynamiczny rozwój komputerów personalnych, którymi zainteresowanie wzrosło po napisaniu pierwszego arkusza kalkulacyjnego VisiCalc przez D. Bricklina (często nazywanego ojcem arkuszy kalkulacyjnych) i B. Franstona. Polscy milenialsi stanowią pokolenie wyżu demograficznego, które było już wychowywane w warunkach gospodarki rynkowej. Charakteryzuje ich biegłość komputerowa oraz internetowa, połączona z otwartością na świat. Cenią oni swobodę przemieszczania się i wolność polityczną, co przejawia się m.in. w niskim udziale w wyborach. W przeciwieństwie do poprzednich pokoleń dużą wagę przywiązują do realizacji swoich potrzeb, a zatem mogą być mniej lojalni w pracy, która nie spełnia ich oczekiwań. Natomiast jeśli się zaangażują w pracę, to przejawiają dużą dozę kreatywności.

Pokolenie Z to jednostki non stop podłączone do sieci, które dopiero zaczynają pojawiać się na rynku pracy. Utożsamiają oni niemalże świat realny z wirtualnym (M. Prensky nazywa tę grupę digital natives - „cyfrowi tubylcy”), dlatego odcięcie ich od sieci powoduje alienację. Pokolenie to jest dobrze wykształcone. Znając języki obce, jest skłonne podejmować pracę nawet poza granicami kraju. Obca jest im stabilność w pracy, a kluczowe staje się samodoskonalenie oraz praca w grupie.

\footnotetext{
${ }^{1}$ M. Prensky (2006). Don't Bother Me Mom - I'm Learning! Saint Paul: Paragon House.
} 
Mimo że nazewnictwo opisanych pokoleń oraz przedział wiekowy powszechnie funkcjonują w literaturze, to nie są one ostatecznie rozstrzygnięte (Smola, Sutton, 2002) i należy je bardziej uznawać za wskazówkę niż za sztywną granicę (Lancaster, Stillman, 2003). Ponadto przedział wiekowy dla klasyfikacji pokoleń należy traktować płynnie, gdyż osoby urodzone w latach granicznych tych przedziałów mogą zostać zakwalifikowane do grupy sąsiedniej (tzw. cuspers - zob. Lancaster, Stillman, 2002). Przykładowo osoba, która urodziła się w 1978 roku, może bardziej wykazywać cechy pokolenia Y niż $\mathrm{X}$. Zaletą tych osób jest to, że ich doświadczenia i pamięć społeczna umożliwiły lepsze rozumienie obu pokoleń i łatwiejsze niwelowanie konfliktów międzypokoleniowych.

W tym miejscu należałoby powrócić do definicji pokolenia W. Straussa i N. Howe’a (1991), w której pojawia się słowo „osobowość”. Według nich kształtuje ona zachowania czy przekonania, które są warunkowane historycznie oraz zdeterminowane przez wartości współdzielone przez określone grupy ludzi. Zatem poza powszechnie przyjętym dwudziestoletnim przedziałem wiekowym pokoleń i ich nazewnictwem można spotkać w literaturze inne grupy pokoleniowe, uwarunkowane specyficznymi zdarzeniami historycznymi, np. pokolenie $9 / 11 \mathrm{w}$ USA naznaczone przez ataki terrorystyczne z 11 września 2001 roku, pokolenie komunistyczne formowane w dawnych krajach socjalistycznych czy pokolenie JP2 (Szawiel, 2008). Oznacza to, że pojawiają się inne propozycje kwalifikujące pokolenia, jak np. kontekst historyczno-społeczny, który może być dodatkowo powiązany z poziomem edukacji (Woodward, Vongswasdi, More, 2015), czasem wejścia na rynek pracy (Joshi, Dencker, Franz, Martocchio, 2010) czy genealogią (Joshi, Dencker, Franz, 2011). Warto podkreślić, że to ostatnie kryterium jest szczególnie istotne w gospodarkach bazujących na firmach rodzinnych.

S. Kurek dokonał analizy zróżnicowania przestrzennego struktury wieku ludności za pomocą metody typografów (Długosz, 1996). Wynika z niej, że w Polsce w okresie poddanym analizie najliczniej reprezentowany jest typ A (wiek przedprodukcyjny oraz młodszy produkcyjny) w województwach podkarpackim, małopolskim, wielkopolskim oraz pomorskim. Badacz ten zaobserwował również występowanie tego typu demograficznego w strefach podmiejskich dużych i średnich miastach. Ujęcie to nie obejmowało jednak pokoleń, a grupy wiekowe. Nie uwzględniało także dynamiki tego zjawiska w skali lokalnej.

Podsumowując, każde pokolenie kształtowane jest przez specyficzne warunki gospodarcze, społeczne oraz historyczne, w którym funkcjonuje. Wyróżnikiem pokolenia mogą być poglądy, wartości, wzorce konsumpcyjne czy etyka pracy, które dodatkowo utrudniają klasyfikację pokoleń. Jednak identyfikacja oraz analiza grup pokoleniowych powinna stanowić istotny element kształtowania gospodarki danego kraju, a nawet regionu. Większość badań różnorodności pokoleniowej koncentruje się na krajach zachodnich (Parry, Urwin, 2011), dlatego w niniejszym artykule podjęto próbę analizy różnorodności pokoleniowej w Polsce jako przykładowym kraju Europy Środkowo-Wschodniej, której gospodarka była planowana centralnie i przez to determinowała określone zachowania społeczne wynikające z kształtowania właściwych dla niej wartości. Ponadto, w celu analizy pokoleń na poziomie regionalnym, wykorzystano wskaźnik obciążenia demograficznego, aby lepiej zobrazować regiony, w których dominuje gospodarka cyfrowa (digital economy), oraz regiony, które rozwijają się w oparciu o tzw. tzw. gospodarkę srebrną (silver economy). Analiza grup pokoleniowych przez włodarzy regionów pozwoli na efektywniejsze pozyskiwanie funduszy oraz na osiąganie przez przedsiębiorstwa regionalnych przewag konkurencyjnych. 


\section{RÓŻNORODNOŚĆ POKOLENIOWA ZASOBÓW PRACY - PODSTAWY METODYCZNE}

Różnorodność pokoleniowa została opisana w literaturze i powszechnie przyjmuje się podział na tradycjonalistów, baby boomers, pokolenie X, pokolenie milenialsów oraz pokolenie Z. Jednak należy pamiętać, że w ramach przedziałów wiekowych dla tych grup pojawiają się odchylenia i podziały należy traktować raczej jako zakresy referencyjne niż definitywne rozgraniczenie ((Ng, Schweitzer, Lyons, 2010). Ponadto na charakterystykę różnorodności pokoleniowej może mieć wpływ ustrój społeczno-polityczno-gospodarczy danego kraju (Lyons, Kuron, 2014). Na potrzeby niniejszej publikacji podziału na grupy pokoleniowe dokonano, uwzględniając specyfikę sektora technologii informacyjno-komunikacyjnych. Dlatego ostatecznie przyjęto do analizy pokolenia tradycjonalistów, milenialsów oraz pokolenie Z, które w najwyższym stopniu przyczyniają się współcześnie do kształtowania różnorodności pokoleniowej. Dokonano przy tym następującego grupowania danych, na potrzeby identyfikacji liczebności poszczególnych pokoleń:

- pokolenie tradycjonalistów - urodzeni w latach 1925-1944; dla tej grupy w analizach przyjęto dane dla osób w wieku co najmniej 65 lat w 2003 i 2016 roku (rozwiązanie to powoduje niepełną porównywalność danych, ale wynika to z braku danych w podziale na grupy dla ludności powyżej 65 roku życia),

- pokolenie Y (milenialsów) - urodzeni w latach 1980-2000; do badania wzięto pod uwagę osoby w wieku 5-25 lat w 2003 roku i 16-34 lat w 2016 roku,

- pokolenie Z - urodzeni po 2000 roku; osoby w wieku 0-2 lata w 2003 roku i 0-15 w 2016 roku.

Analizom poddano przestrzenne zróżnicowanie udziałów poszczególnych pokoleń w strukturze demograficznej, przyjmując podział na klasy o rozpiętości 5\%, dzięki czemu można prześledzić zmiany udziału danego pokolenia w polskiej przestrzeni w podziale według powiatów w 2003 i 2016 roku.

\section{ZRÓŻNICOWANIE POKOLENIOWE POLSKICH REGIONÓW - ANALIZA PORÓWNAWCZA DLA 2003 I 2016 ROKU}

Na sytuację demograficzną w badanym okresie duży wpływ wywarły kolejne słabnące echa wyżu demograficznego, który wystąpił po zakończeniu II wojny światowej, osiągając swój szczyt w 1960 roku, co było związane ze zmianą prawa regulującego dopuszczalność aborcji. Prowadziło to do powolnego starzenia się ludności, aczkolwiek na znacznie mniejszą skalę niż w innych krajach Europy. Od wstąpienia Polski do Unii Europejskiej w maju 2004 roku mamy w Polsce do czynienia z dużymi ruchami wędrówkowymi ludności do krajów UE, szczególnie Wielkiej Brytanii i Republiki Federalnej Niemiec, co przyspiesza proces starzenia się ludności, mimo napływu migrantów z Ukrainy, Białorusi i Rosji.

Temu kierunkowi zmian demograficznych sprzyjały także zmiany na rynku pracy, prowadzące do niskiej stabilności ekonomicznej rodzin w latach 2003-2016, co miało wpływ na model rodziny, dzietność kobiet i wiek matek-pierworódek (Kotowska, Magda, 2017).

Dlatego pokolenie tradycjonalistów zaczęło stanowić liczną grupę w regionach o najsilniejszym odpływie ludności, czyli dość licznych powiatach (48) położonych głównie na wschodzie Polski, w województwach podlaskim, lubelskim, świętokrzyskim, 
Ryc. 1. Udział pokolenia tradycjonalistów w strukturze ludności w 2003 i 2016 roku według powiatów - porównanie
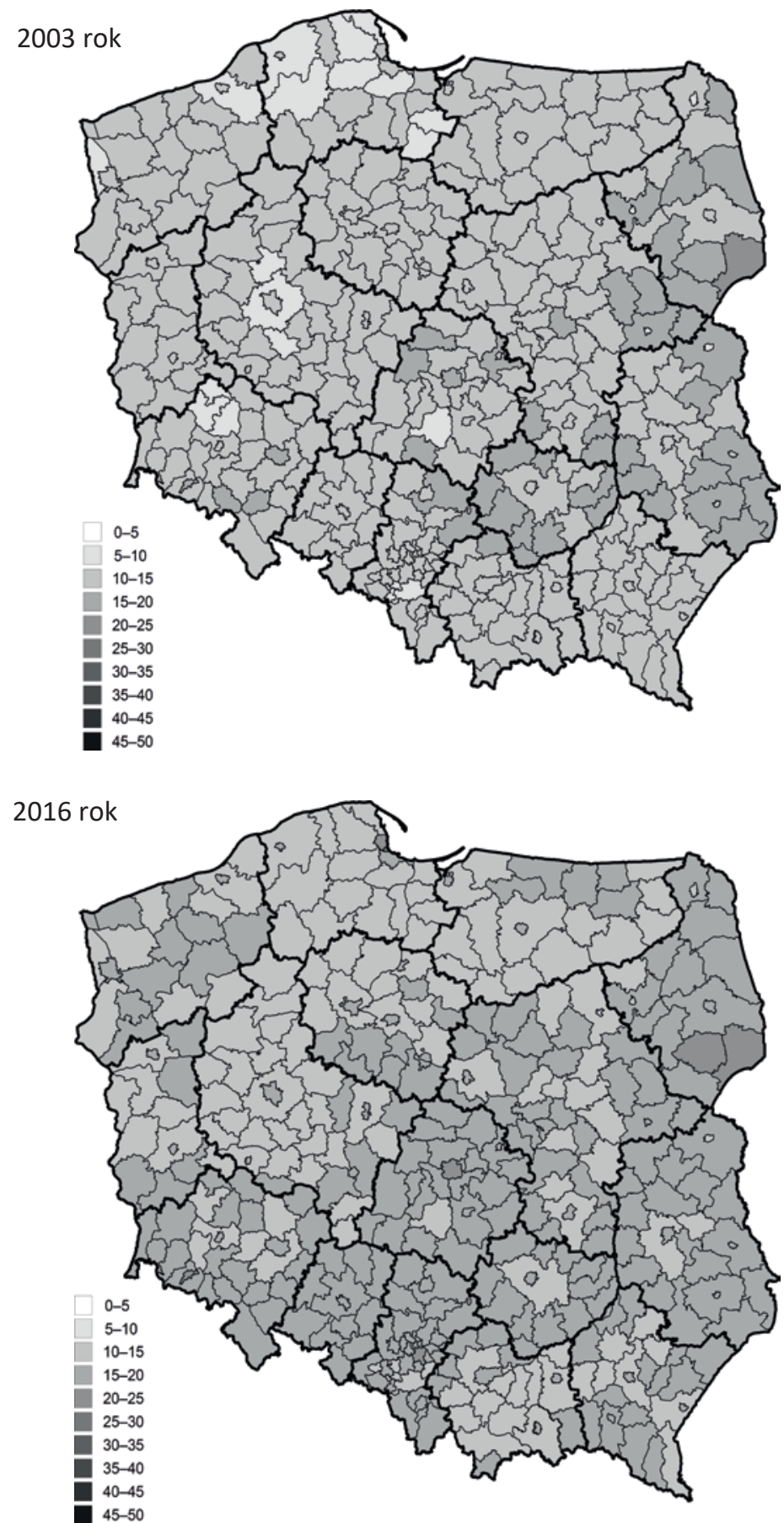

Źródło: opracowanie własne na podstawie BDL GUS 
Ryc. 2. Udział pokolenia milenialsów w strukturze ludności w 2003 i 2016 roku według powiatów - porównanie
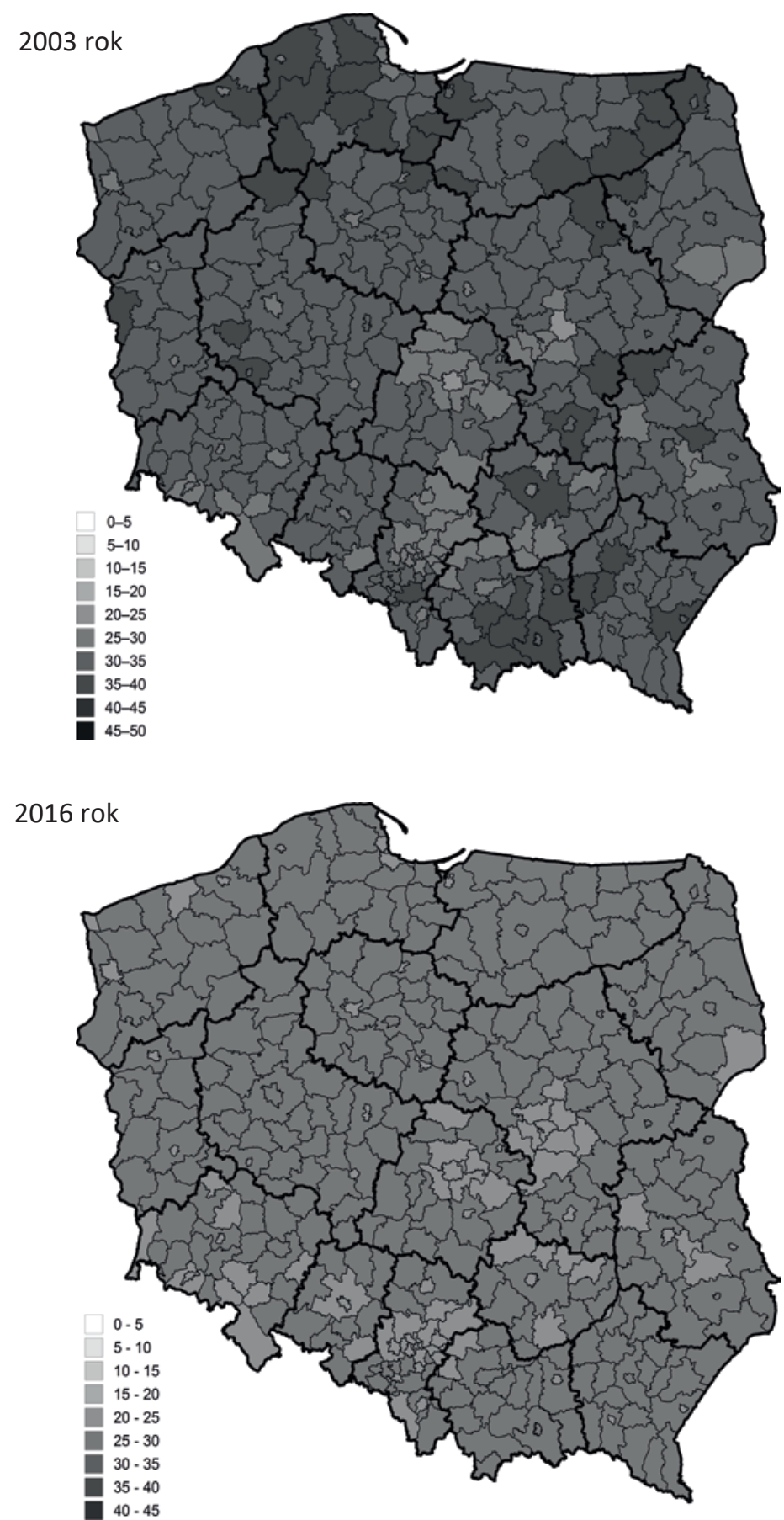

Źródło: opracowanie własne na podstawie BDL GUS 
Ryc. 3. Udział pokolenia Z w strukturze ludności w 2016 roku według powiatów

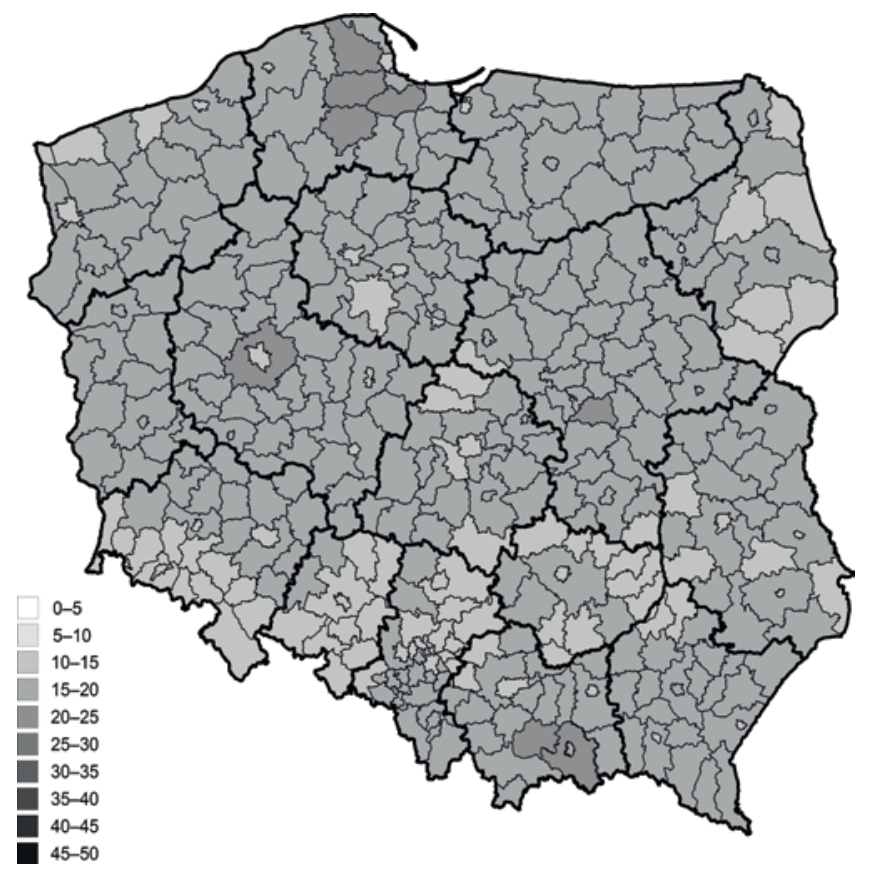

Źródło: opracowanie własne na podstawie BDL GUS

osiągając udziały w granicach 15-20\%, a w powiecie hajnowskim nawet nieznacznie przekraczając $1 / 5$ populacji (por. ryc. 1 ).

W 2016 roku znacznie więcej powiatów (239) osiągnęło co najmniej 1/6 udziału pokolenia tradycjonalistów w ogóle ludności, co uwidacznia znaczne rozprzestrzenianie się obszarów zamieszkałych przez starsze roczniki ludności, urodzone w okresie poprzedzającym koniec II wojny światowej.

Kolejne analizowane przez nas pokolenie to pokolenie milenialsów, czyli osób urodzonych między 1980 a 2000 rokiem.

Roczniki te stanowią grupę osób urodzonych przez liczne matki wyżu powojennego, co powoduje, że są one dość liczne na początku okresu naszej analizy, dopóki nie wzmocniły się zachowania związane z drugim przejściem demograficznym, wzmocnione przez selektywność migracji po wejściu Polski do UE. Dlatego pokolenie milenialsów w 2003 roku stanowiło znaczny odsetek w licznych powiatach odmłodzonych w wyniku powojennych ruchów migracyjnych (zachodnia Polska, szczególnie Pomorze). Udział milenialsów sięgał nawet 35-40\% ogółu ludności (42 powiaty), szczególnie na Pojezierzu Kaszubskim.

Jednak w 2016 roku widoczne jest zmniejszenie się odsetka milenialsów w ogóle społeczności lokalnych w wielu rejonach. Nie odnotowano już tak rekordowo wysokich udziałów milenialsów w strukturze ludności, a dysproporcje pod tym względem wyraźnie się zmniejszyły (por. ryc. 2).

Kolejne pokolenie (pokolenie Z) jest jeszcze mniej liczne, gdyż stanowi efekt kolejnego, jeszcze słabszego echa powojennego wyżu demograficznego. Urodzeni po 2000 
roku stanowili nieznaczną część polskich społeczności lokalnych w 2003 roku. We wszystkich powiatach udział ten nie przekroczył $5 \%$.

Pod wpływem pojawiania się po 2000 roku kolejnych roczników udział tego pokolenia w strukturze demograficznej wzrósł w 2016 roku w wielu powiatach. Ilustrację tego zjawiska stanowi ryc. 3.

Od 1/6 do 1/5 społeczności stanowią oni w rejonach notujących w przeszłości wysokie poziomy stopy urodzeń, dzięki czemu odzywa się tam znowu, choć zmniejszone, echo wyżu demograficznego (Pojezierze Kaszubskie). Nowym zjawiskiem jest natomiast podwyższona dzietność wokół niektórych polskich dużych miast, co wiąże się z rozwojem stref podmiejskich. Przestają one być tylko strefą dojazdów do pracy, ale też zaczynają być miejscem zamieszkania dla młodych rodzin. Taką interpretację można przypisać powiatom: poznańskiemu, piaseczyńskiemu położonemu w strefie podmiejskiej Warszawy czy powiatom okalającym Trójmiasto (gdański, kartuski, wejherowski).

\section{WYZWANIA ZARZĄDCZE W REGIONACH ZRÓŻNICOWANYCH POKOLENIOWO A KREOWANIE ATRAKCYJNOŚCI INWESTYCYJNEJ REGIONÓW}

Wielkim wyzwaniem zarządczym dla jednostek samorządu terytorialnego szczebla regionalnego i lokalnego może stać się różnorodność pokoleniowa, która polega zwłaszcza na istnieniu w danym regionie/rejonie licznych roczników reprezentujących skrajne grupy wiekowe. Przyjmując, że taka sytuacja występuje, jeśli jednocześnie mamy do czynienia z gospodarką milenialsów i dzieci oraz srebrną gospodarką, to rejony o ponad 1/5 udziału zarówno pokolenia Z, jak i tradycjonalistów stanowią największe wyzwanie. W badanym okresie takiej sytuacji nie zanotowano w obu okresach badawczych, ani w skali województw, ani w skali powiatów. Przyczyną tego stanu rzeczy jest postępujące starzenie się ludności, co obrazują pogarszające się systematycznie wskaźniki obciążenia demograficznego (por. ryc. 4).

Obecnie prowadzony program rządowy „Rodzina 500+” może zmienić decyzje dotyczące posiadania potomstwa. Jednak warunek, że pomocy udziela się rodzinom już posiadającym potomstwo, może silnie ograniczyć skuteczność tego rozwiązania na obszarach, w których procesy wymienialności pokoleń są najbardziej zachwiane.

Wymienialność pokoleń jest więc zjawiskiem systematycznie słabnącym. Przeciętnie trzech dziadków przypada na dwóch wnuczków w coraz liczniejszych rejonach Polski, szczególnie na południowym Podlasiu (powiaty hajnowski, bielski), Lubelszczyźnie (powiat krasnostawski), Kielecczyźnie (ostrowiecki, skarżyski, kazimierski, Kielce), a także w miastach będących stolicami regionów lub centrami regionalnymi/subregionalnymi (Łódź, Gdynia, Koszalin, Bydgoszcz, Opole) oraz w pojedynczych mniejszych ośrodkach przemysłowych, transportowych lub usługowych (Świnoujście, Częstochowa). Postępujące starzenie się ludności jest zagrożeniem dla rozwoju gospodarczego.

Dlatego należy podkreślić, że wzrost aktywności i społecznej integracji osób starszych nie jest istotny jedynie dla tej grupy, ale przekłada się na możliwości rozwoju społeczności lokalnych (Golinowska, 2012: 76-85). Z drugiej strony stwarza możliwość rozwoju srebrnej gospodarki, szczególnie w dużych miastach, np. w Łodzi (więcej na temat srebrnej gospodarki: Zimnoch, 2013).

Rozwój srebrnej gospodarki opiera się na takich fundamentach, jak wydłużenie aktywności zawodowej seniorów, przy jednoczesnym utrzymaniu ich samodzielności. 
Ryc. 4. Wskaźnik obciążenia demograficznego w polskich powiatach w 2003 i 2016 roku
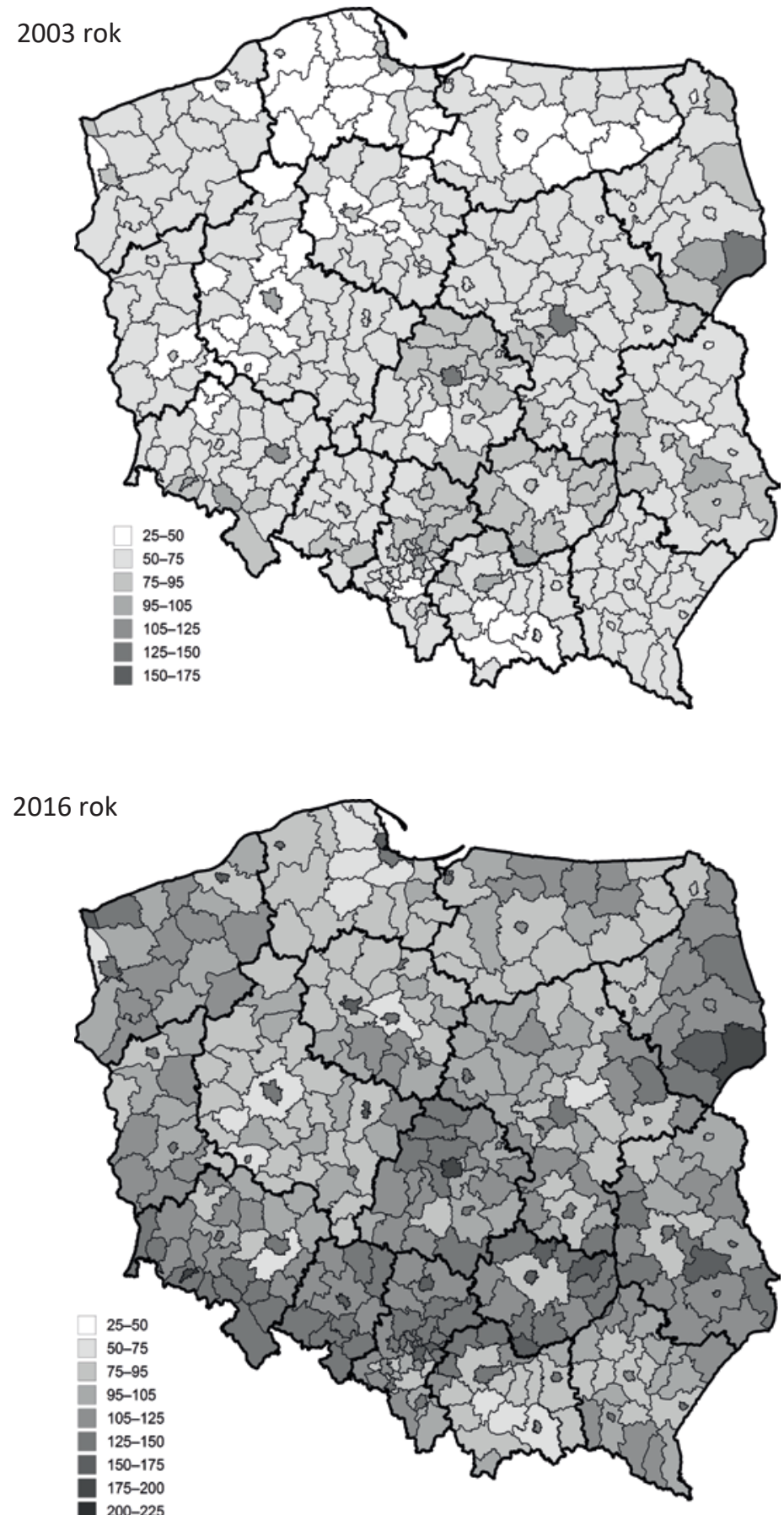

Źródło: opracowanie własne na podstawie BDL GUS 
Ważne jest także zagospodarowanie ich wolnego czasu, utrzymywanie dobrej kondycji fizycznej i psychicznej oraz dostrzeżenie w seniorach atrakcyjnej grupy docelowej dla sektora usług finansowych (Szukalski, 2012: 8).

\section{WNIOSKI}

Największym współczesnym zagrożeniem ekonomicznym jest postępujące starzenie się społeczeństw. Jakość współczesnego życia jest na tyle wysoka, że na rynku pracy zaczęły funkcjonować równocześnie nawet cztery pokolenia. Powoduje to, że polityka finansowo-gospodarcza państw/regionów/powiatów/gmin musi być proaktywna w kwestii aktywizacji zawodowej, gdyż w przeciwnym razie może przyczynić się do globalnego kryzysu spowodowanego nadmiernym obciążeniem budżetów państwowych na rzecz osób starszych. Istotnym wyzwaniem dla rządzących staje się zatem umiejętność aktywizowania zawodowego różnych grup pokoleniowych w taki sposób, aby współpracowały ze sobą w sposób harmonijny i możliwie najbardziej efektywny. Poszukiwanie skutecznych sposobów na promowanie aktywności i zdrowia osób starszych oraz wzmacnianie solidarności międzypokoleniowej nabiera kluczowego charakteru. Należy przy tym brać pod uwagę warunki (technologie), w jakich różne pokolenia egzystowały. Z pewnością w gospodarce cyfrowej kluczową rolę będą odgrywać milenialsi i pokolenie Z, jednak wiedza oraz doświadczenie zgromadzone przez pokolenie, które wyszło z rynku pracy, mogą - i zdaniem autorów powinny - być wykorzystane do podnoszenia innowacyjności regionów.

Zarządzanie różnorodnością pokoleniową powinno uwzględniać zgodną współpracę wszystkich grup, które uczą się wzajemnie, o czym już dawno temu wspominała M. Mead: „jedynie opierając się na młodych, starsze pokolenie może uzyskać dostęp do nowej wiedzy doświadczalnej, bez której nie sposób układać żadnych sensownych planów" (Mead, 1978: 143). Zatem starsze pokolenie może aktywnie przyczyniać się do wykorzystywania nabytej wiedzy na rzecz podnoszenia innowacyjności regionów. Zdaniem autorów, do podnoszenia innowacyjności regionów najbardziej przyczyniać się powinno przenikanie wiedzy i doświadczenia pomiędzy różnymi pokoleniami (przede wszystkim od pokolenia starszego do młodszego).

Przez polskie małe ojczyzny przechodzą zmiany demograficzne, stosownie do kolejnych odsłon echa powojennego wyżu demograficznego. Na to nakładają się skutki selektywności migracji. Rozszerza się gospodarka srebrna, w związku ze starzeniem się ludności i selektywnym charakterem ruchów migracyjnych na wschodzie Polski. Towarzyszy temu silne zahamowanie wymienialności pokoleń.

Milenialsi stanowią w skali kraju pokolenie o zmniejszającym się udziale w zaludnieniu w latach 2003-2016. Ale to właśnie to pokolenie, wraz z nadchodzącym pokoleniem Z, będzie kształtować w najbliższych latach rynek pracy, zwłaszcza w Wielkopolsce, na Pomorzu i Warmii i Mazurach, zważywszy na charakter trendów przestrzennych w kształtowaniu się wymienialności pokoleń.

Współcześnie dużym zagrożeniem dla rozwoju gospodarek, w szczególności cyfrowych, stanowi postępujące starzenie się społeczeństw. Jednak tendencja ta przyczyniła się do powstania tzw. srebrnej gospodarki, która może nieść za sobą wiele korzyści, jak np. rozwój opieki dla seniorów. Zatem z perspektywy zarządzania regionem istotne jest analizowanie trendów demograficznych oraz ich wpływu na gospodarkę regionu, a w szczególności tendencji demograficznych dotyczących pokoleń milenialsów i Z oraz osób w wieku poprodukcyjnym. 
Zmiany w zarządzaniu zasobami pracy powinny bazować na jak najszerszym wprowadzaniu metod służących zarządzaniu różnorodnością pokoleniową, szczególnie w odniesieniu do stosowania nowoczesnych technologii oraz ułatwiania komunikacji międzypokoleniowej w miejscu pracy.

Zarządzanie różnorodnością pokoleniową stanowi również duże wyzwanie w kontekście politycznym, gdyż to głównie osoby starsze głosują w wyborach, a zatem partie mogą prowadzić agitacje wśród tej grupy osób, wiedząc, że działanie takie przełoży się na wynik wyborczy. Jednak takie działania prowadzą w konsekwencji do nadmiernego obciążenia finansowego regionów, ograniczając tym samym działania nakierunkowane na rozwój młodych. W dłuższej perspektywie prowadzić to może do drenażu młodych i w konsekwencji upadku regionu.

\section{Literatura \\ References}

Almeida, P., Kogut, B. (1999). Localization of knowledge and the mobility of engineers in regional networks. Management Science, 45(7), 905-917.

Breschi, S., Lissoni, F. (2005). Cross-firm inventors and social networks: localized knowledge spillovers revisited. Annals of Economics and Statistic, 79(80), 189-209.

Costanza, D., Badger, J., Fraser, R. (2012). Generational differences in work-related attitudes: A meta-analysis. Journal of Business and Psychology, 27(4), 375-394.

Dencker, J.C., Joshi, A., Martocchio, J.J. (2008). Towards a theoretical framework linking generational memories toworkplace attitudes and behaviors. Human Resource Management Review, 18(3), 180-187.

Długosz, Z. (1996). Zróżnicowanie struktury wieku na świecie a metody jej klasyfikacji. Przegląd Geograficzny, 68(1-2), 151-165.

Eberhardt, P. (2014). Fazy rozwoju demograficznego Polski. Roczniki Nauk Społecznych, 6(2), 135-160.

Edmunds, J., Turner, B.S. (2005). Global generations: social change in the twentieth century. The British Journal of Sociology, 56(4), 559-577.

Eisenstadt, S.N. (1956). From Generation to Generation. Glencoe: Free Press.

Elmore, T. (2010). Generation iY: Our last chance to save their future. Norcross: Gardener Publishing.

Erikson, E.H. (2012). Dopełniony cykl życia. Gliwice: Helion.

Eyerman, R., Turner, B.S. (1998). Outline of a theory of generations. European Journal of Social Theory, 1(1), 91-106.

Giancola, F. (2006). The generation gap: More myth than reality? Human Resource Planning, 29(4), 32-37.

Golinowska, S. (2012). Srebrna gospodarka i miejsce w niej sektora zdrowotnego. Koncepcja i regionalne przykłady zastosowania. Zdrowie Publiczne i Zarządzanie, 1(2011).

Halbwachs, M. (1950). La mémoire collective, Paris: Albin Michel.

Joshi, A., Dencker, J.C., Franz, G. (2011). Generations in organizations. Research in Organizational Behavior, 31(1), 177-205.

Joshi, A., Dencker, J.C., Franz, G., Martocchio, J.J. (2010). Unpacking generational identities in organizations. Academy of Management Review, 35(3), 392-414.

Kaiser, U., Kongsted, H.C., Rønde, T. (2015). Does the mobility of R\&D labor increase innovation? Journal of Economic Behavior\& Organization, 110, 91-105.

Kelan, E.K. (2014). Organising Generations - What Can Sociology Offer to the Understanding of Generations at Work? Sociology Compass, 8(1), 20-30.

Kotowska, I.E., Magda, I. (2017). Polityka rodzinna i podaż pracy w Polsce. W: P. Lewandowski, J. Rutkowski (red.). Starzenie się ludności, rynek pracy i finanse publiczne w Polsce. Warszawa: Przedstawicielstwo Komisji Europejskiej w Polsce. 
Kryńska, E. (2010). Wpływ zmian demograficznych na rynek pracy - aspekty gospodarcze. Rzadowa Rada Ludnościowa. Biuletyn, 55, 29-37.

Kurek, S. (2014).Przestrzenne zróżnicowanie przemian demograficznych w Polsce w latach 2002-2011. W: E. Klima (red.). Ludność, mieszkalnictwo, usługi - w 70. rocznicę urodzin Profesora Jerzego Dzieciuchowicza. Population, Housing, Services - 70th Anniversary of Professor Jerzy Dzieciuchowicz. Łódź: Wydawnictwo Uniwersytetu Łódzkiego.

Lancaster, L., Stillman, D. (2002). When generations collide. Who they are. Why they clash. How to solve the generational puzzle at work. New York: HarperCollins Publishers.

Lancaster, L.C., Stillman, D. (2003). When generations collide. New York: Harper-Collins Publisher.

Loges, W.E., Jung, J.-Y. (2001). Exploring the digital divide: Internet connectedness and age. Communication Research, 28(4), 536-562.

Lyons, S., Kuron, L. (2014). Generational differences in the workplace: A review of the evidence and directions for future research. Journal of Organizational Behavior, 35(1), 139-157.

Maliepaard, M., Lubbers, M., Gijsberts, M. (2010). Generational differences in ethnic and religious attachment and their interrelation. A study among Muslim minorities in the Netherlands. Ethnic and Racial Studies, 33(3), 451-472.

Mannheim, K. (1952). The Sociological Problem of Generations. Essays on the Sociology of Knowledge. London: RKP.

Mansfield, E. (1985). How rapidly does new industrial technology leak out. The Journal of Industrial Economics, 34(2), 217-213.

Martin, C.A., Tulgan, B. (2002). Managing the generational mix. Amherst: HRD Press.

Mead, M. (1978). Kultura i tożsamość: studium dystansu międzypokoleniowego. Warszawa: Państwowe Wydawnictwo Naukowe.

Mendel, G. (2006). Une histoire de l'autorité. Paris: La Découverte.

Miller, W.E., Shanks, J.M. (1996). The New American Voter. Cambridge: Harvard University Press.

Murphy, E.F., Gordon, J.D., Anderson, T.L. (2004). Cross-cultural, cross-cultural age and cross-cultural generational differences in values between the United States and Japan. Journal of Applied Management and Entrepreneurship, 9(3), 21-47.

Ng, E.S.W., Schweitzer, L., Lyons, S.T. (2010). New generation, great expectations: A field study of the millennial generation. Journal of Business and Psychology, 24(2), 281-292.

Noble, S.M., Haytko, D.L., Phillips, J. (2009). What drives college-age Generation Y consumers? Journal of Business Research, 62(6), 617-628.

Oh, E., Reeves, T.C. (2014). Generational Differences and the Integration of Technology. W: J.M. Spector, M.D. Merrill, J. Elen, M.J. Bishop (red.). Handbook of Research on Educational Communications and Technology. New York: Springer, 819-828.

Parry, E., Urwin, P. (2011). Generational differences in work values: A review of theory and evidence. International Journal of Management Reviews, 13(1), 79-96.

Reither, E.N., Hauser, R.M., Yang, Y. (2009). Do birth cohorts matter? Age-period cohort analyses of the obesity epidemic in the United States. Social Science \& Medicine, 69(10), 1439-1448.

Rogers, E.M. (1995). Diffusion of innovations. New York: Free Press.Saxenian, A. (1994). Regional advantage: Culture and competition in Silicon Valley and Route 128. Cambridge: Harvard University Press.

Segal, H.P. (1985). Technological utopianism in American culture. Chicago: University of Chicago Press.

Shaw, H. (2013). Sticking points: How to get 4 generations working together in the 12 places they come apart. Carol Stream: Tyndale House Publishers.

Shelley, M.C., Thrane, L.E., Shulman, S.W. (2006). Generational differences in information technology use and political involvement. International Journal of Electronic Government Research, 2(1), 36-53.

Shelley, M.C., Thrane, L.E., Shulman, S.W. (2015). Generational differences in it use and political involvement: New directions. W: D. Norris (red.). E-Government research. Policy and management. Hershey: IGI Publishing, 336-357.

Shelley, M., Thrane, L., Shulman, S., Lang, E., Beisser, S., Larson, T., Mutiti, J. (2004). Digital citizenship: Parameters of the digital divide. Social Science Computer Review, 22(2), 256-269. 
Shore, L. M., Chung-Herrera, B. G., Dean, M., Ehrhart, K. H., Jung, D. I., Randel, A. E., Singh, G. (2009). Diversity in organizations: Where are we now and where are we going? Human Resource Management Review, 19(2), 117-133.

Smola, K., Sutton, C.D. (2002). Generational differences: revisiting generational work values for the new millennium. Journal of Organizational Behavior, 23(4), 363-382.

Stillman, D., Stillman, J. (2017). Gen Z @ Work: How the next generation is transforming the workplace. New York: Harper Business.

Strauss, W., Howe, N. (1991). Generations: The history of America's future 1584 to 2069. New York: Morrow.

Szawiel, T. (2008). Pokolenie JP2: przeszłość i przyszłość zjawiska religijnego. Warszawa: Wydawnictwo Naukowe Scholar.

Szukalski, P. (2012). Trzy kolory: srebrny. Co to takiego silver economy? Polityka Społeczna, 5-6.

Śleszyński, P. (2016). Współczesne i prognozowane uwarunkowania demograficzno-migracyjne w rozwoju miejskiego systemu osadniczego Polski. Konwersatorium Wiedzy o Mieście, 1(29), 97-106.

Wilhelm, A.G. (2000). Democracy in the digital age: Challenges to political life in cyberspace. New York: Routledge.

Winner, L. (1977). Autonomous technology: Techniques-out-of-Control as a theme in political thought. Cambridge: MIT Press.

Woodward, I.C., Vongswasdi, P., More, E.A. (2015). Generational diversity at work: A systematic review of the research. INSEAD Working Paper,48/OB.

Zemke, R., Raines, C., Filipczak, B. (2000). Generations at work: Managing the class of veterans, boomers, $x$-ers, and nexters in your workplace. New York: Amacon.

CBOS (2013). Komunikat z badania „Zadowolenie z pracy i jej oceny”. Pozyskano z https://www. cbos.pl/SPISKOM.POL/2013/K_010_13.PDF

Zimnoch, K.(2013). Starzenie się i srebrna gospodarka w uwarunkowaniach rozwojowych Podlasia. Optimum. Studia Ekonomiczne, 4(64), 25-36.

Hanna Godlewska-Majkowska, prof., Kolegium Nauk o Przedsiębiorstwie, prorektor do spraw współpracy z otoczeniem, opiekun Studenckiego Koła Naukowego Przedsiębiorczości i Analiz Regionalnych, Szkoła Główna Handlowa w Warszawie. Zainteresowania naukowo-badawcze: lokalizacja przedsiębiorstw, przedsiębiorczość regionalna, atrakcyjność inwestycyjna i konkurencyjność regionów, marketing terytorialny, źródła sukcesu i zagrożeń MSP, organizacje inteligentne w MSP, zarządzanie finansami JST.

Hanna Godlewska-Majkowska, professor, Collegium of Business Administration, Vice Rector for Outreach, coordinator of Students' Scientific Groupon Entrepreneurship and Regional Analyses, Warsaw School of Economics. Research interests: location of enterprises, regional entrepreneurship investment attractiveness and competitiveness of regions, territorial marketing, Small and Medium Enterprises (sources of success, threats, intelligent organisations), financial management of local government units.

\section{Adres/address:}

$$
\begin{aligned}
& \text { Szkoła Główna Handlowa } \\
& \text { Kolegium Nauk o Przedsiębiorstwie } \\
& \text { al. Niepodległości 162, 02-554 Warszawa, Polska } \\
& \text { e-mail: hgodle@sgh.waw.pl }
\end{aligned}
$$

Jacek Lipiec, dr, Kolegium Nauk o Przedsiębiorstwie, Szkoła Główna Handlowa w Warszawie. Zainteresowania naukowo-badawcze: przedsiębiorczość rodzinna, zarządzanie zasobami ludzkimi, finanse.

Jacek Lipiec, Ph.D., Collegium of Business Administration, Warsaw School of Economics. Research interests: family entrepreneurship, human resource management, finance.

\section{Adres/address:}

Szkoła Główna Handlowa w Warszawie

Kolegium Nauk o Przedsiębiorstwie

al. Niepodległości 162, 02-554 Warszawa, Polska

e-mail: jlipiec@sgh.waw.pl 